\title{
EVALUATION OF A COMPUTER-BASED TEACHING PROGRAMME (CBTP) DEVELOPED FOR STUDENT NURSES IN AN ONCOLOGY CLINICAL SETTING
}

\author{
Annemarie Joubert \\ $\mathrm{PhD}$ \\ School of Nursing, University of the Free State \\ Corresponding author: gnvkaj@med.uovs.ac.za

\section{Marlene J Viljoen} \\ DSocSc \\ School of Nursing, University of the Free State \\ Jacobus A Venter \\ $\mathrm{PhD}$ \\ School of Nursing, University of the Free State
}

Keywords: Authoring systems; Computer-based teaching; Computer-based teaching programme; Hypermedia; Hypertext

\section{SAMEVATTING}

'n Rekenaargebaseerde onderrigprogram (RGOP) is na 'n omvattende literatuurstudie oor leer, leerteorieë, -style en benaderings, tradisionele-, studentgesentreerde- en onderrig deur hipermedia, en rekenaargebaseerde onderrig ontwikkel, met die doel om 'n onderrigbenadering te implementeer waar studentverpleegkundiges die geleentheid gegun word om verantwoordelikheid vir leer te aanvaar, leerbehoeftes te identifiseer en 'n diep benadering tot leer te volg. Kriteria wat tydens die ontwikkeling van die RGOP in ag geneem is, is onder drie kategorieë, naamlik onderrigeffektiwiteit, kosmetiese-, program- en kurrikulumdoeltreffendheid geklassifiseer en uiteindelik gebruik om 'n evalueringsinstrument saam te stel. Die evalueringsinstrument het ook die volgende hoof- en subkriteria ingesluit (sien Tabel 1):

- Onderrigeffektiwiteit: Ontwerp, Prosedure, Effektiwiteit, Duidelikheid

- Kosmetiese doeltreffendheid: Voorkoms, Duidelikheid

- Program doeltreffendheid: Ontwerp

- Kurrikulum doeltreffendheid: Ontwerp \& inhoud

Nadat die RGOP vir 'n tydperk van twee maande of 'n maksimum van ses ure deur respondente wat aan die navorsing deelgeneem het gebruik is, is dit deur hulle aan die hand van die instrument geëvalueer. Die navorsing is in twee situasies, naamlik in die verpleegpraktyk (twee maande), waar minder beheer oor die respondente se benutting van die RGOP moontlik was, en ook in 'n multimediarekenaarsentrum (MMS) (ses ure), geloods. 'n Vergelyking word getref tussen die resultate van die groep in die praktyk $(n=40)$ en dié van 'n groep wat in 'n multimediarekenaarsentrum (MMS groep) $(n=20)$ in gekontroleerde omstandighede op dieselfde program gewerk het. Om vas te stel of daar 'n statisties betekenisvolle verskil tussen die twee groepe se persentasie (binne elke afdeling van die instrument behaal) bestaan, is daar dus van die nie-parametriese Mann-Whitney toets en 95\% nie-parametriese vertrouensintervalle gebruik gemaak. 'n Statisties betekenisvolle verskil tussen die groepe word aangedui deur $p<0.5$ en die vertrouensinterval wat die waarde 0 uitsluit. Die mediaanverskil tussen die praktyk en MMS groep is as volg: Ten opsigte van onderrigeffektiwiteit (duidelikheid) was die mediaan vir beide groepe 100\%. Die mediane van beide groepe, het ten opsigte van al die kategorieë baie min verskil en het tussen $81.67 \%$ en $100 \%$ gewissel. 


\section{ABSTRACT}

A computer-based teaching programme (CBTP) was developed after a comprehensive review of the literature with regard to learning, learning theories, traditional and student-centred styles and approaches, teaching through hypermedia and computer-based teaching. The aim was to implement a teaching approach whereby student nurses would be given the opportunity to accept responsibility for learning, to identify learning needs and to follow a deep approach to learning. The criteria taken into account in the development of the CBTP were classified into three categories, namely teaching effectiveness, cosmetic, programme and curriculum effectiveness and were eventually used to compile an evaluation instrument. The evaluation instrument also included the following main and subcriteria (see Table 1):

- Teaching effectiveness: Design, Procedure, Effectiveness, Clarity

- Cosmetic effectiveness: Appearance, Clarity

- Programme effectiveness: Design

- Curriculum effectiveness: Design and content

After the CBTP had been used for a period of two months or a maximum of six hours by the respondents who took part in the research, the respondents evaluated the programme with the aid of the instrument. The research was carried out in two situations, i.e. in nursing practice (two months), where less control of the respondents' utilisation of the CBTP was possible, and in a multimedia computer centre (MMC) (six hours). A comparison was made between the results of the group in practice $(n=40)$ and those of a group who worked on the same programme under controlled circumstances in a multimedia computer centre (MMC) $(n=20)$. To ascertain whether there was a statistically significant difference between the percentages of the two groups within each section of the instrument, the non-parametric Mann-Whitney test and 95\% non-parametric confidence intervals were used. A statistically significant difference between the groups is indicated by $p<0.5$ and the confidence interval that excludes the value 0 . The median difference between the practice group and the MMC group was as follows: As regards teaching effectiveness (clarity) the median for both groups was $100 \%$. There was very little difference between the medians of both groups in all the categories. It varied between $81.67 \%$ and $100 \%$.

\section{INTRODUCTION}

An extensive literature search was undertaken to identify and apply important criteria in the development of a computer-based teaching program (CBTP) for student nurses in oncological clinical practice. An instrument developed to evaluate the CBTP included the main and subcriteria as set out (See Table 1).

\section{Table 1: Evaluation instrument for a computer-based teaching programme}

\section{COMPUTER-BASED TEACHING: EVALUATION INSTRUMENT}

Answer the questionnaire by making an $\mathrm{X}$ in the space provided.

1. Very poor: Not acceptable (amend).

2. Below average: Almost meets set ideal.

3. Average: Meets the requirements for a well-designed programme but characteristic is not unique.

4. Above average: Unusual method or ability to achieve the required focus.

5. Very good: Excellent/innovative/unique. 


\section{A. TEACHING EFFECTIVENESS}

\section{Design}

1.1 Clear instructions provided about how to use data (information)

1.2 Content provides for various learning approaches, namely:

1.2.1 Superficial learning

1.2.2 Deep learning

1.3 Content is easily understandable

$1.4 \quad$ Content is free of vague concepts

1.5 Content is appropriate for the situation in which it will be used

1.6 Content is presented in logical sequence

$1.7 \quad$ Content is factually/professionally correct

\section{Procedure}

$2.1 \quad$ Instructions are easy to follow

$2.2 \quad$ Students can work without supervision

2.3 Students are allowed to work at their own tempo regarding:

2.3.1 control of how long information appears on the screen

2.3.2 amount of content

2.3.3 depth of content

2.4 Amount of content that appears on the screen is appropriate

2.5 Students will find content:

2.5.1 interesting

2.5.2 appropriate

2.6 Manner of presentation will motivate students to utilise the "programme"

2.7 Opportunities are offered for interaction between students and content:

2.7.1 select content of choice (menu)

2.7.2 select content in terms of own learning objectives

2.7.3 possibility of printing out content

2.7.4 variety of keys

2.8 Concepts are clearly indicated 


\begin{tabular}{|ll|}
\hline 2.9 & Concepts are scientifically defined \\
\hline 2.10 & Social interaction is promoted by allowing students to work together in groups \\
\hline 2.11 & Links: Linked content is appropriate \\
\hline 2.12 & Retention of content can be promoted \\
\hline 3. Effectiveness \\
\hline 3.1 & Help function is available \\
\hline 3.2 & Help function is user-friendly (helps user) \\
\hline 3.3 & Students can quit program when/if they wish \\
\hline 3.4 & Students can continue programme later at the same place \\
\hline 3.5 & Keys are consistently used (e.g. back, quit) \\
\hline 3.6 & Program content cannot be accidentally changed by students \\
\hline 4. Clarity \\
\hline 4.1 & Font legible \\
\hline
\end{tabular}

\section{B. COSMETIC EFFECTIVENESS}

\section{Appearance}

5.1 Space on screen is effectively used, i.e. piling up of content is avoided

5.2 Typographic layout is consistent for easy localisation of content

5.3 Use of colour supports learning by students

5.4 Colour images (e.g. anatomy) clear, i.e. detail can be identified

\section{Clarity}

6.1 Scrolling of content acceptable

6.2 Content free of spelling mistakes

\section{PROGRAMME EFFECTIVENESS}

\section{Design}

8.1 Instructions are carried out as desired

\subsubsection{Assessment instruments}

8.1.2 Nursing actions

8.1.3 Concepts

8.1.4 Information 


\begin{tabular}{|ll|}
\hline 8.1 .5 & Nursing diagnoses \\
\hline 8.1 .6 & Anatomy \\
\hline 8.1 .7 & Print \\
\hline 8.1 .8 & Quit \\
\hline 8.1 .9 & Back \\
\hline 8.1 .10 & Next \\
\hline 9. & Content. Text spaced within frame \\
\hline 10. & Cutting off words avoided \\
\hline 11. & Terminology used correctly \\
\hline 12. & Language suitable for target group \\
\hline 13. & Recording of marks \\
\hline 14. & Menus or main menu: \\
\hline 14.1 & takes student to appropriate content \\
\hline 14.2 & layout done sensibly \\
\hline
\end{tabular}

\section{CURRICULUM EFFECTIVENESS}

\section{Design}

15.1 Procedures to obtain information are consistent

15.2 Content will not change with the next 18 months

15.3 Individualising of learning is promoted

15.4 Content is interesting

15.5 Content is appropriate for target group

16. Do you believe that a computer-based teaching program such as the one you have just used can be used in clinical practice to train student nurses?

16.1 Please motivate your reply.

\section{SURVEY OF THE LITERATURE}

According to Lennon and Maurer $(1994: 5,8)$ approaches to the presentation of lectures have changed a great deal in the past ten years. The overhead projector has taken the place of the blackboard and this teaching aid is now being superceded by computerbased offerings.

Traditionally computer-based teaching was characterised by the highly linear structure in which information was presented. This lecturer-centred 
approach was especially useful for learning behaviour, for example stimulus-response strengthening (Cronje, 1994:47; Sinclair \& Gardner, 1997). However, rapid changes in the field of computer technology require continuous adaptation in approaches.

New hypermedia authoring systems that can be used for the development of computer-based programmes takes into account among others, cognitive and intelligence models, human factors, as well as psychological and social aspects of man (Rada, Wang \& Michailidis, 1994:27; Nagelkerk, Ritola \& Vandort, 1998:17-21). The fact that individuals gain access to information in different ways and interact with it differently is considered to be extremely important (Louw, 1994:118; Fletcher-Flinn \& Gravatt, 1995:219-241; Game, 1996:20-22; Fisher \& Parkinson, 1998:232236; Lowry \& Johnson, 1999:521-526).

Usefulness and user-friendliness of hypermedia authoring systems are also taken into account when systems are developed, and currently multidata computer-based information management tools make it possible for the user or designer to be interactively in control of a set of dynamic, purposeful links portraying the underlying structure of the knowledge base (Louw, 1994:117).

The use of hypermedia is ideal for a deep learning approach as "ramifications" and the multiple possibilities of presentation make it a very suitable instrument for cognitive learning (Cronje, 1994:47). The three main learning processes, namely gaining knowledge, problem-solving and the search for information, are according to Louw (1994:118), backed by the use of hypermedia.

Hypertext, together with multimedia, forms a building block for hypermedia. A feature of hypertext is the linking of information, the non-linear presentation made possible and its highly interactive nature. Linking may include graphics, video images or sound. The non-linear presentation of information was predicted by Bush as early as 1945 (De Wet, 1994:53, 61; Ritchie, 1994:41).

CBTP must comply with criteria such as effectiveness of education (design, procedure, effectiveness and clarity), cosmetic effectiveness (appearance and clarity), programme effectiveness (instructions, terminology and layout), and curriculum effectiveness (change in content, individualisation of learning and interest of the content (Hannafin \& Peck, 1988:296-324; Burger, 1991:4-6; Tolhurst, 1992:17-21; Posel, 1993:273-276).

Teaching effectiveness refers to the clarity of instructions, the provision made for different learning styles, the logical sequence of content, the help function, the font, etc. Cosmetic effectiveness refers, among others, to the use of colour and the typographic layout of each screen. Programme effectiveness refers to the instructions provided to the users and the terminology and layout of the CBTP. Lastly, curriculum effectiveness refers to the possibility that content may change, individualisation of learning and how interesting the content is.

\section{CONCEPTS}

\section{Computer-based teaching}

Computer-based teaching encompasses all activities in which computer systems are used in teaching. This also refers to the teaching process, namely recordkeeping and evaluation of students' progress (Saba \& McCormick, 1986:362).

\section{Computer-based teaching programme (CBTP)}

The CBTP is a learning programme developed by the researcher for student nurses in an oncology clinical setting. It was developed to promote students' cognitive and problem-solving skills, as well as a deep active learning approach. Specific criteria were taken into account in its development.

\section{Hypermedia}

Hypermedia is a multidata computer-based information management tool in which the user is interactively in control of a set of dynamic purposeful links portraying the underlying structure of the knowledge base (Louw, 1994:117).

\section{Hypertext}

Hypertext is characterised by the linking of information, the non-linear presentation that is possible and its highly interactive nature. Linking may include graphics, video image and sound (De Wet, 1994:53 and 61; Ritchie, 1994:41). 


\section{Multimedia computer centre (MMC)}

The multimedia computer centre (MMC) is situated in the Department of Nursing and is equipped with eighteen computers, seven of which have hard drives. The CBTP is loaded onto all these computers. The centre has sufficient space where respondents may study. It is open daily from $08 \mathrm{~h} 00$ to $13 \mathrm{~h} 00$ and $14 \mathrm{~h} 00$ to $16 \mathrm{~h} 00$ and could easily be utilised by respondents.

\section{Authoring systems}

Authoring systems allow designers to develop computer-supported lectures and computer-based teaching material by means of the computer (Saba \& McCormick, 1986:75).

\section{Nursing practice}

The Department of Oncology comprises several sections, for instance a clinic, a radiotherapy and research section and four nursing care units. The four nursing care units or wards were easily available. All ethnic groups are treated in these wards.

\section{AIM AND OBJECTIVE OF THE RE- SEARCH}

The aim of the research was to evaluate a computerbased teaching programme (CBTP) developed for student nurses in an oncology clinical setting.

More specifically the objective was to evaluate the computer-based teaching programme (CBTP) against a set of criteria that such a programme should meet.

\section{SAMPLES}

The target population for the research consisted of student nurses registered for the generic program in nursing at a nursing college and a university.

\section{Sample size}

Factors taken into account for the selection of the size of the samples were the type of study, the nature of the evaluation instrument and the techniques of data analysis.

The following samples were selected:

Students in their first and/or second year of study at two nursing education institutions placed in oncology wards for clinical experience. A convenience selection was used. Inclusion criteria for these respondents were that they had to be placed in an oncology ward for a two-month period. This resulted in a sample of forty $(n=40)$ respondents.

To improve the validity and reliability of the research a second sample was selected. This sample only included nursing students at a university. The reason for this selection was that the MMS facilities used for the implementation of the CBTP provided easy access to this group. First, second and third year students voluntarily participated in the research. This resulted in a sample of twenty $(n=20)$ respondents.

According to the researcher the selection of respondents from different years of study did not pose a problem for the reliability or validity of the research. This was based on the fact that all students were exposed to a computer-based programme especially designed for the oncology clinical setting for the first time, and the fact that respondents at that stage had only been exposed to oncology nursing for a period of two months. Content regarding oncology nursing and placement in the oncology ward is presented at different stages of training in the two institutions involved.

\section{RESEARCH METHOD AND DESIGN}

A quantitative method and comparative descriptive design were used (Burns \& Grove, 1987:56, 61-68, 269).

\section{RESEARCH TECHNIQUES}

The CBTP programme developed for student nurses in an oncology clinical setting was evaluated by means of a Likert type structured questionnaire.

The questionnaire was completed by all the respondents and consisted of the following four sections:

- Section A dealt with the teaching effectiveness of the programme and included four subjects, namely design, procedure, effectiveness and clarity. The criteria for the subjects were formulated in questions and referred to:

The clarity of the instructions

- $\quad$ The provision made for various learning styles 
The logical sequence of content

The help function

The font

Section B evaluated cosmetic effectiveness and included two subjects, namely appearance and clarity. Questions asked in this regard dealt, among others, with the use of colour and the typographic layout.

- $\quad$ Section $\mathrm{C}$ included programme effectiveness and dealt with the instructions given to the respondents, the terminology and the layout. Section $D$ evaluated curriculum effectiveness. Questions in this regard dealt, among others, with the possible change in content, individualisation of learning and interest of the content.

\section{PILOT STUDY}

The approach to the evaluation of the CBTP was both quantitative and pragmatic. Before implementation the programme was evaluated by three experts in oncological nursing (a lecturer and two chief professional nurses), three experts in computer-based teaching and four student nurses from the target population who were not selected as respondents. The evaluation was regarded as formative. Evaluation forms were compared and the evaluators were found to have agreed to a large extent. Criteria that attained an average mark of three or less out of five on the Likert scale were reviewed and amendments made accordingly.

\section{RELIABILITY AND VALIDITY}

The reliability of the instrument was not statistically determined by means of the alpha coefficient, as the items or criteria that were included had no bearing on a specific construct. According to a conversation with experts in this field (Huysamen \& van Zyl, UFS, 1996), the statistic calculation of reliability was not significant. The possibility of doing a re-test after a fortnight to determine reliability was considered. Due to the scope of the research and the logistical problems associated with the implementation of such a step, it was decided that its omission would not have a negative effect on the study.

\section{DATA ANALYSIS}

Descriptive and inferential statistics were used to process the data. Frequencies and means were used, among others. Correlations were calculated where they applied. The inferential statistical analyses included medians, frequencies and the Mann-Whitney test.

\section{ETHICAL ISSUES}

In the opinion of the researcher the evaluation of the CBTP held no ethical risks.

\section{VALUE OF THE RESEARCH}

The identification of criteria, which a CBTP must meet, can contribute to the development of computer-based nursing education programmes of high quality.

\section{DEFICIENCIES}

The researcher believes that respondents should have used the CBTP for a longer period. This could have enhanced the reliability and validity of the evaluation of the programme.

\section{RESULTS}

First a score was calculated for each section of the assessment instrument, for instance Section A's subsection "design" included a total of $8 \times 5=40$ points, and "Procedure" $18 \times 5=90$ points.

The percentage that respondents obtained in each section was calculated. As these scores were not normally divided either, they were described by means of the median (or minimum and maximum).

Statistically significant differences between the scores of the practice and MMC group were calculated by using the non-parametric Mann-Whitney test and 95\% non-parametric confidence intervals. A statistically significant difference between the groups is indicated by $p<0.5$ and the confidence interval, which excludes the value 0 .

\section{EVALUATION OF THE COMPUTER- BASED TEACHING PROGRAMME BY THE PRACTICE AND MMC GROUPS}

Teaching effectiveness (design, procedure, effective 
ness and clarity), cosmetic effectiveness, programme effectiveness and curriculum effectiveness were evaluated. Reference was first made to the total percentages (scores) obtained by the practice and MMC groups in all the items. The percentage that respondents obtained for each section was calculated. As these scores were not distributed in a normal manner, they were calculated by means of the median (or minimum and maximum).
The non-parametric Mann-Whitney and 95\% nonparametric confidence intervals were used in order to establish whether there was a statistically significant difference between the two groups' percentages obtained within each section. A statistically significant difference between the groups is indicated by $p<0.5$ and the confidence interval, which excludes the value 0 .

Table 2 illustrates the results of the evaluation of the CBTP by the respondents in the practice and MMC groups.

Table 2: Respondents' evaluation of the effectiveness of the CBTP in the practice and MMC groups

\begin{tabular}{|c|c|c|c|c|c|}
\hline ITEM & $\begin{array}{l}\text { Median } \\
\text { Practice } \\
\mathrm{N}=40\end{array}$ & $\begin{array}{l}\text { Median } \\
\text { MMC } \\
\mathrm{N}=20\end{array}$ & $\begin{array}{l}\text { Median of } \\
\text { differences } \\
\text { (practice- } \\
\text { MMC) }\end{array}$ & $\begin{array}{l}95 \% \text { VI for } \\
\text { median of } \\
\text { differences }\end{array}$ & $\begin{array}{l}\text { p-value } \\
\text { Mann- } \\
\text { Whitney }\end{array}$ \\
\hline \multicolumn{6}{|l|}{ Training effectiveness } \\
\hline - Design & 86.3 & 90.0 & -2.5 & $-7.5 ; 5.0$ & 0.42 \\
\hline - Procedure & 81.7 & 84.4 & 0.0 & $-10.0 ; 7.78$ & 0.94 \\
\hline - Effectiveness & 83.3 & 81.7 & 0.0 & $-10.0 ; 6.67$ & 0.92 \\
\hline - Clarity & 100 & 100 & 0 & $0.0 ; 0.0$ & -.66 \\
\hline Cosmetic effectiveness & 88.3 & 88.3 & 0 & $-6.67 ; 6.67$ & 0.86 \\
\hline Programme effectiveness & 90.0 & 89.5 & 1.05 & $-5.26 ; 7.37$ & \\
\hline Curriculum effectiveness & 88.0 & 90.0 & 0 & $-8.0 ; 8.0$ & 0.80 \\
\hline
\end{tabular}

It may be deduced from the above table that, as far as the Mann-Whitney test and the 95\% non-parametric confidence intervals are concerned, there were no statistically significant differences in any section.

The responses of the various groups to the various items, which were evaluated, are set out below:

\section{Practice group $(n=40)$}

The percentages (scores) for subjects and median difference for the subject design were calculated. Respondents assigned a maximum of $100 \%$ and a minimum of $67.5 \%$. For procedure, there was a big difference in percentage, the highest being $100 \%$ and the lowest
$21 \%$. This low percentage may possibly be ascribed to a technical problem experienced with the printer. A maximum of $100 \%$ was assigned to most sections while the minimum percentage was assigned as follows: $56.6 \%$ for teaching effectiveness, $80 \%$ for clarity (which in this case applied to the legibility of the font), $63.3 \%$ for cosmetic effectiveness and $60 \%$ for programme effectiveness. Curriculum effectiveness obtained a minimum of $64 \%$.

\section{MMC group $(n=20)$}

This group's evaluation of the CBTP was different from that of the practice group. The percentages (scores) were high throughout with $80 \%-100 \%$ for clarity, 
$72.6 \%-100 \%$ for programme effectiveness - design and $72 \%-100 \%$ for curriculum effectiveness.

\section{Practice $(n=40)$ and MMC $(n=20)$}

The median difference between the practical and MMC groups were calculated. In respect of teaching effectiveness (clarity) the median for both groups was 100\%. The medians of both groups showed very little difference in respect of all the categories and ranged between $81.67 \%$ and $100 \%$.

\section{CONCLUSIONS AND RECOMMENDA- TIONS}

It is clear from the data analysis that the CBTP met the criteria of teaching, cosmetic, programme and curriculum effectiveness. The researcher recommends that the criteria be used as a guideline for the development of computer-based programmes. Findings of follow-up studies may be used to refine the criteria and evaluation instrument.

\section{REFERENCES}

BURGER, M 1991: Kriteria en prosedures vir die evaluering van opvoedkundige rekenaarprogramme. Infomedia, Mei:4-6.

BURNS, N \& GROVE, SK 1987: Practice of nursing research: Conduct, critique and utilization. London: WB Saunders Company. CRONJE, J 1994: Hypermedia and contemporary learning theory. (In: Hypermedia '94. $2^{\text {nd }}$ Southern African conference on multimedia and hypermedia. Pretoria: March, pp. 47-51.)

DE WET, M 1994: Practical development in hypermedia and multimedia for computer assisted language learning (CALL). (In: Hypermedia '94. $2^{\text {nd }}$ Southern African conference on multimedia and hypermedia. Pretoria: March, pp. 60-64.)

FISHER, DL \& PARKINSON, C 1998: Improving nursing education classroom environments. Journal of Nursing Education, 37(5):232-236.

FLETCHER-FLINN, CI \& GRAVATT, B 1995: The efficacy of computer-assisted instruction (CAI): A meta-analysis. Journal of Educational Computing Research, 12:219-241.

GAME, C 1996: Nursing-related information and data: What is the role of computers in nursing practice? Collegian, 3:20-22.

HANNAFIN, MJ \& PECK, KL 1988: The design, development, and evaluation of instructional software. London: Collier Macmillan Publishers.

HUYSAMEN, \& VAN ZYL, 1996: Interview with author, regarding the statistical calculation of the reliability and validity of instruments, UFS.

LENNON, J \& MAURER, H 1994: Lecturing technology: A future with hypermedia. Educational Technology, April:5-14.

LOUW, WJA 1994: Hypertext and its use in education. (In: Hypermedia '94. $2^{\text {nd }}$ Southern African conference on multimedia and hypermedia. Pretoria: March, pp. 117-124.)

LOWRY, M \& JOHNSON, M 1999: Computer assisted learning: The potential for teaching and assessing in nursing. Nursing Education Today, Oct., 19(7):521-526.

NAGELKERK, J; RITOLA, PM \& VANDORT, PJ 1998: Nursing informatics: The trend of the future. Journal of Continuing Education in Nursing, Feb., 29(1):17-21.

POSEL, N 1993: Guidelines for the evaluation of instructional software by hospital nursing departments. Computers in Nursing, November/December:273-276.

RADA, R; WANG, W \& MICHAILIDIS, A 1994: A model for collaborative hypermedia and reuse of courseware. (In: Hypermedia ' $94.2^{\text {nd }}$ Southern African conference on multimedia and hypermedia. Pretoria: March, pp. 27-39.)

RITCHIE, I 1994: Hypertext - a brief overview. (In: Hypermedia '94. 2nd Southern African conference on multimedia and hypermedia. Pretoria: Hypermedia '94, March, 23-25, pp. 41-46.) SABA, VK \& McCORMICK, KA 1986: Essentials of computers for nurses. Philadelphia: Lippincott.

SINCLAIR, M \& GARDNER, J 1997: Nurse teachers' perceptions of information technology: A study of nurse teachers in Northern Ireland. Journal of Advanced Nursing, 25(2):372-376.

TOLHURST, D 1992: A checklist for evaluating content-based hypertext computer software. Educational Technology, March:1721. 